\title{
ONLINE-BASED MARKETING MANAGEMENT IMPLEMENTATION (Empirical Study of MSMEs in the Furniture Sector in Tasikmalaya)
}

\author{
Lucky Radi Rinandiyana, Tine Badriatin \\ Siliwangi University \\ tinebadriatin@gmail.com
}

\begin{abstract}
The marketing problem is one of the problems that often arises by MSME business people. Where most MSME business people still rely on the marketing process by using old methods to introduce their business products while the recent economic growth is growing very rapidly, plus the support of advancing technology indirectly encourages furniture and furniture entrepreneurs to increase production. the lack of knowledge of MSME practitioners in using existing technology as promotional media certainly becomes an obstacle in the marketing process of MSME furniture production. Most of the SMEs in Jln Tamansari Gobras, Tasikmalaya City, only 70\% understand and apply the concept of online-based marketing in introducing the results of furniture production, where MSMEs still use banners or banners for media promotion and sales management still using manual methods, so that sales reach very limited. The purpose of this study was to determine the implementation of online-based marketing management concepts in the development of online-based marketing management business and the role of online-based marketing implementation in increasing sales turnover in MSME furniture and furniture production in the village of Tamansari Gobras in Tasikmalaya City. This research uses a descriptive method. The results showed that Babakan Muncang Tamansari Gobras MSMEs, the City of Tasikmalaya had to increase their knowledge to do online marketing to increase their income without having to spend a lot of funds as capital which experienced a $3.8 \%$ decline in sales then to expand their market share by selling online. SMEs in the village of Babakan Muncang Tamansari Gobras in the City of Tasikmalaya are expected to implement online marketing management to bring reservations without having to come directly to the place of business.
\end{abstract}

Keywords: Marketing; Online Sales

* Corresponding author's e-mail: tinebadriatin@gmail.com 
EAJ (Economics and Accounting Journal) - Vol. 3, No. 2, May 2020 - Rinandiyana \& Badriatin

\section{INTRODUCTION}

This rapid technological development has brought many changes to the patterns of life of some Indonesian people. The pattern of life occurs in almost all fields, both social, cultural, trade and other fields. In the field of commerce, the internet has begun to be used as a medium for business activity mainly because of its contribution to efficiency. Trading activities through internet media are popularly called electronic commerce (e-commerce). Ecommerce is divided into two segments, namely business to business ecommerce (trade between businesses) and business to consumer e-commerce (trade between businesses and consumers).

To implement the above law, it is necessary to have proper management, in this case, online marketing management. Marketing management is the analysis and supervision of programs aimed at creating exchanges with the intended market with a view to achieving company goals. While marketing itself is a whole system of business activities proposed to plan, price, promote and distribute goods and services that satisfy needs, both to existing and potential buyers.

Marketing is one of the main activities that need to be carried out by the MSME, both goods and services companies. In the era of increasingly competitive business competition, every business person who wants to win the competition in the market will pay full attention to the marketing strategy that is carried out his.

One of the main problems that becomes an obstacle in marketing is the number of competitors in the market itself, both from similar products and other products. This is a big responsibility that must be won by those MSME if you want to continue to exist in business competition. increasingly intense competition and changes that continue to occur must be made a lesson by marketing management in order to proactively anticipate changes both for the present and the future.

Marketing activity or marketing in a business is the spearhead that determines the continuity of the business. With the right strategy will make the product or service known to the audience, increase sales volume and ultimately generate high profits as well. But mistakes in marketing also often occur which are caused by ignorance or lack of experience of the businessperson in carrying out marketing.

Implementation of online-based marketing to increase sales is still difficult for MSME practitioners to implement. Limited knowledge about how to replace the old system of sales with a new system that is based online marketing is considered not important for MSMEs and is a reason for MSMEs not to implement online based marketing. resulting in MSMEs not being able to develop their marketing targets broadly. In fact, sometimes sales are only limited between villages.

The explanation above concludes that by implementing online-based marketing the MSMEs will be able to increase their sales reach wider and faster so that the turnover will also increase.

Based on the initial survey that has been done, the writer found that most of the MSMEs in Tamansari Babakan Muncang, Tasikmalaya City did not understand and apply the concept of online-based sales in running their businesses. The MSMEs still rely on media banners for promotional media, which causes advertisements to not reach the wider community and the difficulty of consumers to know the products that are available up-to-date, while to transact consumers must directly come to the MSME sales location.

This problem usually arises because the knowledge and information of MSMEs 
about online-based marketing management is still very limited. The amount of contribution / influence of online marketing strategies on consumer buying interest, there is a positive and significant relationship between online marketing strategies on consumer buying interest (Jati, Waluyo. Et. al., 2017)

\section{LITERATURE REVIEW}

1. The Concept of Marketing Management

In creating customer satisfaction, the company must be able to analyze, plan, implement and control its marketing activities. This is done by carrying out marketing management. Understanding of Marketing Management according to Kotler and Armstrong (2010: 5), understanding marketing management as follows: "Marketing Management is the art and science of choosing target markets and reaching, maintaining, and growing customers by creating, delivering and communicating superior customer value."

Meanwhile, according to Alma (2007: 130), defines as follows: "Marketing management is the activity ofanalyzing, planning, implementing, and overseeing all activities (programs), in order to obtain a favorable exchange rate with target buyers in order to achieve organizational goals."

According to Assauri (2013: 12), "Marketing management is an activity of analyzing, planning, implementing, and controlling programs created to form, build, and maintain profits from exchanges through market targets in order to achieve organizational goals (companies) in the long term. ".

While Understanding of Marketing Management according to Philip Kotler (2009: 5) is "Marketing Management is the process of planning and implementing, thinking, pricing promotion, and channeling ideas of goods and services to create exchanges that meet individual goals in the organization"

According to Suparyanto \& Rosad (2015: 1) marketing management is the process of analyzing, planning, managing, and managing programs that include conceptualization, pricing, promotion and distribution of products, services and ideas designed to create and maintain profitable exchanges with target market to achieve company goals. Kotler \& Keller (2009: 5) defines marketing management as the art and science of choosing targeted markets and reaching, retaining, and growing customers by creating, delivering and communicating superior customer value.

Marketing management is a process carried out to analyze, plan, coordinate programs that benefit the company, and can also be interpreted as the science of choosing market share in order to create superior customer value.

From the description it can be said that marketing management not only serves to determine and increase demand in the market, but also to change and regulate these requests. So marketing management tries to set the level, time and order of the existing requests, in order to help the organization in achieving its goals.

2. Online Based Marketing

a. E-Marketing Concept

According to Chen-Ling, \& Lie, in the Journal of the American Academy of Business (2006: 296), e-marketing is the process of marketing products and services to customers using web media. Promotion,

Advertisements, Transactions and payments can be made through web pages. Internet marketing users can easily access information anywhere with a computer connected to the internet.

According to El-Gohary (2010: 216), Electronic Marketing (EMarketing) can be seen as a new philosophy and modern 
EAJ (Economics and Accounting Journal) - Vol. 3, No. 2, May 2020 - Rinandiyana \& Badriatin

business practice involved with marketing goods, services, information and ideas through the internet and other electronics. According to Mohammed, et al. (2003: 4), internet marketing is a process to build and maintain relationships with customers through online activities as a means for the exchange of opinions, products, and services so as to achieve the shared goals of both groups.

According to Jagdish \& Sharma (2005: 612), e-marketing creates fundamental behavioral changes in business and consumers similar to those related to the introduction of cars and phones which reduce the need for a channel approach. e-marketing uses the internet as a platform that allows companies to adapt to customer needs, reduce transaction costs, and allow customers to move anytime and anywhere without worrying about place and time.

Based on the opinion of Mohammed et.al (2003, 96-97) the influence of internet marketing on the company's marketing strategy there are 4 ways namely:

1. Increased segmentation

With the internet market segmentation getting wider, because of the increasingly broad marketing reach. The internet does not limit the breadth of marketing reach because all consumers around the world can access it easily.

2. Develop strategies more quickly in cycle time

With a faster and easier flow of time, marketing strategies can also be more quickly developed.

3 . Increased accountability of marketing efforts

Information that can be obtained quickly and easily can improve the company's strategy to be further improved. So marketing can be done more transparently.

4. Increasing the integration of marketing strategies with business operational strategies
The integration between the company's marketing strategy and marketing strategy through the internet will improve business strategies and operational strategies

3. Basic Elements of Online Marketing Online marketing is the use of the internet and related digital technologies to achieve marketing objectives and support the concept of modern marketing. Spalter (1996) has developed 7 basic elements (7's) of internet marketing (online marketing), namely: 1. Interconection refers to the development of new distribution networks for goods, services and information through various kinds of digital media that exist today. The ability to connect with a large number of customers with a wide reach directly at once, or can be called asynchonously, is a central change that is needed in the marketing perspective when moving towards online marketing.

2. The interface is very important for online marketing to create a userfriendly website. The interface is the first point of contact between the company and the customer, therefore it is designed to be more functional and attractive.

3. Marketers' involvement is demanded to be able to create an online atmosphere that is conducive to encourage expansion and repeat visits from consumers.

4. Information, product information that is widespread in the internet brings the opposite of the database marketing strategy that the company does. the intention is that consumers can do information technology databases to target products in the same way that marketers do to target their customers.

5. Individualsm is the ability and willingness of marketers to provide customized products or experiences depending on the combination of technology, effective marketing 
EAJ (Economics and Accounting Journal) - Vol. 3, No. 2, May 2020 - Rinandiyana \& Badriatin

research and the characteristics of the product.

6. Integrity, privacy, security and comfort of online marketing activities must be ensured. Integriras of the website will affect the success and reputation of the company both in the real world and the internet.

Benefits that can be given with the use of E-Marketing for companies according to Jamal (2001), namely:

1. Able to reach various consumers in an environment that has not been fulfilled by competitors.

2. Targets are consumers who have been divided into groups and develop ongoing dialogue.

Based on the above opinion it can be concluded that online-based marketing can have benefits, namely:

1. Not limited by time because it can be accessed 24 hours

2. Broader market reach even to foreign countries

3. Reducing marketing costs because there is no need to physically make outlets and also do not need brochures, banners and so on.

4. Facilitate entrepreneurs to establish relationships with consumers through interactive communication by using chat room discussion or e-mail

5. Internet marketing strategies can provide more value in the face of competition.

The facts above show online-based marketing is something that is very promising for investors, able to reach a wider market, bring web visitors to increase product sales turnover significantly.

\section{RESEARCH METHOD}

The research method used in this research is descriptive method. The use of descriptive method in this research is to explain and describe the phenomena related to the role of applying the concept of online-based marketing in enhancing business development in the MSME sector in the hamlet of Babakan Muncang Tamansari Gobras in Tasikmalaya City.

This research is a type of qualitative research, where qualitative research is to obtain in-depth data, a data that contains meaning. Research using a qualitative approach can affect the substance of research. This means that quantitative research directly presents the nature of the relationship between researchers and informants, objects and research subjects.

The detailed description of the method used includes the stages of the study, the location of the study, the observed or measured variables, the model used, the research design, and data collection and analysis techniques.

\section{RESULTS AND DISCUSSION}

1. Utilization of the Development of Existing Technology to Support Business Activities of MSMEs.

Based on the results of respondents' answers through a questionnaire distributed to 92 MSMEs in Tamansari Babakan Village to find out how to utilize current technological developments to support business activities at the Babakan Muncang village village in Tamansari Gobras, Tasikmalaya City. This was obtained from the results of the respondents' answers as follows:

Table 1

Results of Respondents' Answers

\begin{tabular}{|c|c|c|}
\hline $\begin{array}{c}\text { Already utilizing the } \\
\text { development of } \\
\text { existing technology } \\
\text { to support business } \\
\text { activities }\end{array}$ & Frequency & Percentage \\
\hline Yes & 28 & $30 \%$ \\
\hline No & 64 & $70 \%$ \\
\hline Amount & $\mathbf{9 2}$ & $\mathbf{1 0 0 \%}$ \\
\hline
\end{tabular}


EAJ (Economics and Accounting Journal) - Vol. 3, No. 2, May 2020 - Rinandiyana \& Badriatin

From table 1 it is known that the majority of MSMEs in Kawalu District have not utilized the current technological developments to support business activities. This shows thatmost of the MSME business operators in Tamansari Village manage sales in a manual manner.

From table 1 where the author gives a score of 1 for each answer "Yes" and a score of 0 for each answer "No", then the average results obtained from questions asked to respondents obtained a percentage of $30 \%$ or a weighted score of 0.30 . Referring to the Guttman Scale the figure is at a moderately low association (moderately weak association) which shows the MSMEs in the village of Tamansari have not consistently utilized the current technological developments to support business activities. The factor that makes MSMEs in Tamansari village not yet consistent in utilizing current technological developments to support business activities is due to the lack of knowledge of how to make online marketing management strategies in developing their businesses.

The results above are also the authors affirmed from the results of interviews with MSMEs who have and have not utilized current technological developments to support business activities, obtained an answer that, "Among us, there are those who have utilized current technological developments to support business activities and some are not yet. this is clear because basically between those who use and those who do not have in common that we do not fully understand will take advantage of the current technological developments to support business activities.

2. How to Promote online Product for MSMEs

Based on data processing regarding business development which aims to find out how to promote products online at MSME Babakan Muncang Tamansari Gobras City in Tasikmalaya, as seen from year-to-year sales turnover are presented in the following table:

Table 2

Average Business Development

\begin{tabular}{|c|r|c|}
\hline Mean & N & $\begin{array}{c}\text { Std. } \\
\text { Deviation }\end{array}$ \\
\hline$-3,8370 \%$ & 92 & $11,94334 \%$ \\
\hline
\end{tabular}

From table 2 it is known that the majority of UMKM furniture and furniture industry actors in Tamansari village have experienced a decline in business. This can be seen from the Mean value of $-3.8370 \%$, which means the average decline in sales decreased by $3.837 \%$ from the previous year. The decrease in business experienced by MSME entrepreneurs in the Kawalu District of Tasikmalaya City is because there are competitors who manage their business using digital technology, so that consumers can easily transact or order online.

\section{Online Order Services Support}

Based on the results of respondents' answers through a questionnaire distributed to 92 MSMEs in Tamansari Babakan Village to find out how to make it easier for consumers to place an order without having to come directly to the place of business located in Babakan Muncang Village, Tamansari Gobras, Tasikmalaya City. This was obtained from the results of the respondents' answers as follows:

Table 3

Results of Respondents' Answers 
EAJ (Economics and Accounting Journal) - Vol. 3, No. 2, May 2020 - Rinandiyana \& Badriatin

From table 3 it is known that the majority of MSMEs in Kawalu District have not been able to facilitate consumers in ordering without having to come directly to a place of business located in Babakan Muncang Village, Tamansari Gobras, Tasikmalaya City, managing sales by hand.

From table 3 where the author gives a score of 1 for each answer "Yes" and a score of 0 for each answer "No", then the average results obtained from questions asked to respondents obtained a percentage of $34.78 \%$ or a weighted score of 0.3478. Referring to the Guttman Scale the figure is in a moderately low association (moderately weak association) which shows the MSMEs in the Tamansari village have not been able to facilitate consumers in making an order without having to come directly to the place of business in Babakan Muncang Village, Tamansari Gobras, Tasikmalaya City

The factor that made MSMEs in Tamansari village not yet able to facilitate consumers in making reservations without having to come directly to a place of business was due to a lack of knowledge on how to make it easier for consumers to place an order without having to come directly to the place of business in Babakan Muncang Tamansari Village Gobras City of Tasikmalaya .

The results above also emphasize the authors of the results of interviews with MSMEs who have and have not been able to facilitate consumers in ordering without having to come directly to the place of business, obtained an answer that, "So far we have not been able to facilitate consumers in ordering without having to come directly to the place of business ".

\begin{tabular}{|c|c|c|}
\hline $\begin{array}{c}\text { Make it easier for } \\
\text { consumers to place an } \\
\text { order without having to } \\
\text { come directly to the } \\
\text { place of business }\end{array}$ & Frequency & Percentage \\
\hline Yes & 32 & $34.78 \%$ \\
\hline No & 60 & $65.22 \%$ \\
\hline Amount & $\mathbf{9 2}$ & $\mathbf{1 0 0 \%}$ \\
\hline
\end{tabular}

\section{CONCLUSION}

Based on the results of the above research, it can be concluded several things as follows.

1. Most respondents have not taken advantage of the current technological developments to support business activities in the MSME business in the village of Babakan Muncang Tamansari Gobras in Tasikmalaya City. Where from the data that has been taken only $34.78 \%$ of businesses that have used technology in marketing their products are still using manuals.

2. Most respondents have not promoted products online at the MSME Babakan Muncang Tamansari Gobras village in Tasikmalaya. So it is inferior to competitors who have used online marketing to facilitate consumers in ordering and making transactions.

3. Most respondents have not made it easier for consumers to place an order without having to come directly to the place of business in the village of Babakan Muncang Tamansari Gobras Tasikmalaya City

\section{REFERENCES}

Alma, Buchori. (2011). Manajemen Pemasaran, Bandung: Alphabeta

Armstrong, G dan Kottler, P. (2004). Dasar-Dasar Pemasaran-Jilid 2 Edisi 6, Jakarta: Intermedia.

Assauri, S. (2013). manajemen pemasaran. Jakarta: Rajawali Pres 
EAJ (Economics and Accounting Journal) - Vol. 3, No. 2, May 2020 - Rinandiyana \& Badriatin

Chandra. (2001). Mencapai Posisi Top Management. Jakarta; PT. Elex

Chen-Ling, F. Dan Ting, L. (2006). Assessment of Internet Marketing and Competitive Strategies for Leisure Farming Industry in Taiwan. Journal of American Academy of Business, 8(2), 296300.

El-Gohary. (2010). $e$, Marketing a literature review from a small bussinesess pervektibe. International kornal of bussiness Nearwork education.

Jagdish \& Sharma. (2005). Performance evaluation and comparison of shahi.

Jamal, A. Dan Goode , M. (2001). Consumer and Brand : a Study of the Impact of Self - Image Congruence on Brand Preference and Satisfaction. Marketing Intelligence \& Planning. 19(7), 482-492.

Kotler,P. dan Keller,KL. (2009). Process Modeling Communication of the ACM. ori, international journal of computer. Kotler,P. dan Amstrong, G. (2010). Manajemen Pemasaran-AnalisisEdisi 7, Jakarta: Lembaga Penerbit Fakultas Ekonomi Universitas Indonesia.

Mohammed et.al. (2003). Internet Marketing Building Advantage.
In A Nerworked Economy, $2^{\text {nd }}$

Edition : McGraw Hill. Singapore.

Spalter, M. (1996). Maintaining a Customer Focus in an Interactive Age, the seven l's to Succes. in Ed Forrest and Richard Mizerski (Eds.), Interactive Marketing : The Future Present, American Marketing Association, NTC Business Books, Illionis.

Swastha, B. (2008). Pengantar Bisnis Modern, Liberty, Yogyakarta

Sugiyono. (2013). Statistik Untuk Penelitian, Cetakan kedelapan Bandung, CV. Alfabeta.

Suparyanto \& Rosad. (2015). Dasardasar Manajemen Pemasaran. Jakarta : Salemba.

Syafarudin, (2015). Analisis Data Penelitian Ekonomi dan Manajemen. Jakarta : Grasindo Waluyo, Jati et al. (2017). Pengaruh Strategi Pemasaran Online (Online Marketing Strategy) terhadap Minat Beli Konsumen (Studi Kasus pada yoko online Azzam Store). Jurnal Pemasaran Kompetitif Manajemen Pemasaran, 1(1), 127-138. 